\title{
Contextos, aplicações e noções de inovação nos documentos oficiais da SED/SC: Nova proposta de ensino inovador em filosofia
}

\author{
Contexts, applications and innovation in the official documents of SED/SC: New proposal for \\ innovative teaching in philosophy \\ Contextos, aplicaciones y nociones de innovación en documentos oficiales de SED/SC: Nueva \\ propuesta de enseñanza innovadora en filosofía
}

Recebido: 22/06/2021 | Revisado: 28/06/2021 | Aceito: 30/06/2021 | Publicado: 13/07/2021

\author{
Léo Cezar Padova \\ ORCID: https://orcid.org/0000-0001-7833-7007 \\ Secretaria Estadual de Educação de Santa Catarina, Brasil \\ E-mail: leocezarpadova@gmail.com \\ Márcio Paulo Cenci \\ ORCID: https://orcid.org/0000-0002-3438-0545 \\ Universidade Franciscana, Brasil \\ E-mail: mpcenci@ufn.edu.br \\ Marcos Alexandre Alves \\ ORCID: https://orcid.org/0000-0002-5271-0624 \\ Universidade Franciscana, Brasil \\ E-mail: marcosalves@ufn.edu.br
}

\begin{abstract}
Resumo
O artigo aborda a noção de inovação na literatura científica e nos documentos oficiais elaborados pela Secretaria de Educação, do Estado de Santa Catarina - SED/SC, com especial destaque para inovação no ensino de Filosofia. Busca-se entender nas propostas curriculares os diferentes contextos e as aplicações do conceito de inovação. Analisa-se os documentos e cadernos de ensino apresentados pelos novos modelos de ensino integral e inovador. Identifica-se as principais defasagens no ensino tradicional, em busca de um ponto de equilíbrio e a criação de condições para um processo inovador em educação. A inovação e o empreendedorismo, no Ensino Médio, possibilitam transformações no ambiente escolar, nas relações pedagógicas e no processo de ensino e aprendizagem, e qualificam os jovens para a vida e o trabalho. A inovação passa pela prática interdisciplinar, criatividade do professor e sua inventividade em termos metodológicos e estratégias de ensino, novo desenho curricular, gestão escolar, planejamento pedagógico, uso de tecnologias, novos modelos de avaliação, juntamente com o empreendedorismo das instituições, estimuladas pelo Estado, enquanto responsável pelas políticas educacionais.
\end{abstract}

Palavras-chave: Inovação; Empreendedorismo; Educação; Ensino; Ensino de filosofia; Criatividade.

\begin{abstract}
The article addresses the notion of innovation in scientific literature and in official documents prepared by the Department of Education, of the State of Santa Catarina - SED/SC, with special emphasis on innovation in the teaching of Philosophy. It seeks to understand in the curriculum proposals the different contexts and applications of the concept of innovation. The teaching documents and notebooks presented by the new integral and innovative teaching models are analyzed. The main gaps in traditional education are identified, in search of a balance and the creation of conditions for an innovative process in education. Innovation and entrepreneurship in high school enable changes in the school environment, in pedagogical relationships and in the teaching and learning process, and qualify young people for life and work. Innovation involves interdisciplinary practice, teacher creativity and inventiveness in methodological terms and teaching strategies, new curriculum design, school management, pedagogical planning, use of technologies, new assessment models, together with the entrepreneurship of institutions, stimulated by the State, as responsible for educational policies.
\end{abstract}

Keywords: Innovation; Entrepreneurship; Education; Teaching; Teaching of philosophy; Creativity.

\section{Resumen}

El artículo aborda la noción de innovación en la literatura científica y en los documentos oficiales elaborados por el Departamento de Educación, del Estado de Santa Catarina - SED / SC, con especial énfasis en la innovación en la enseñanza de la Filosofía. Busca comprender en las propuestas curriculares los diferentes contextos y aplicaciones del concepto de innovación. Se analizan los documentos didácticos y cuadernos presentados por los nuevos modelos de enseñanza integrales e innovadores. Se identifican las principales brechas en la educación tradicional, en busca del 
equilibrio y la creación de condiciones para un proceso innovador en educación. La innovación y el emprendimiento en el bachillerato posibilitan cambios en el entorno escolar, en las relaciones pedagógicas y en el proceso de enseñanza y aprendizaje, y capacitan a los jóvenes para la vida y el trabajo. La innovación involucra la práctica interdisciplinaria, la creatividad e inventiva docente en términos metodológicos y estrategias de enseñanza, nuevo diseño curricular, gestión escolar, planificación pedagógica, uso de tecnologías, nuevos modelos de evaluación, junto con el emprendimiento de las instituciones, estimulado por el Estado, como responsable de las políticas educativas.

Palabras clave: Innovación; Emprendimiento; Educación; Enseñanza; Enseñanza de la filosofía; Creatividad.

\section{Introdução}

O presente artigo aborda o conceito de inovação, voltando a atenção para o ensino da Filosofia, na educação básica. Evidencia-se no caso do ensino de Filosofia, em suas prerrogativas, as seguintes habilidades e competências: constituir cidadãos críticos, capacitados para conhecer, fazer, conviver e ser agentes promotores de soluções aos desafios emergentes, bem como o mercado do trabalho, suas interações sociais, éticas, morais e suas vidas. Questiona-se: quais são as concepções de inovação que permeiam os documentos orientadores do ensino, como às Propostas Curriculares de Santa Catarina (PC/SC), disponibilizados pela Secretaria Estadual de Educação de Santa Catarina (SED/SC), para o período 1983 - 2019, e como elas se articulam com o ensino de Filosofia, na educação básica, e suas contribuições na área de Ciências Humanas?

O estudo intenciona compreender as concepções de inovação frente aos desafios do século XXI, ao promover novas reflexões, discussões e debate sobre a temática: o discurso da inovação e as influências no ensino da Filosofia, com vistas a contribuir para melhorar as políticas públicas educacionais relacionadas ao campo da inovação, bem como suas influências nos processos de ensino e aprendizagem da Filosofia. Trata-se de aprofundar o debate acerca das influências e concepções de inovação no ensino dessa disciplina, ou seja, a proposta consiste em defender que muito da inovação, na área de ensino, passa pela abertura à pluralidade metodológica, pela análise e pelo entendimento de alguns documentos oficiais, planejamento didático em sintonia com as referências teóricas atualizadas, emprego de recursos tecnológicos, aplicação de atividades pedagógicas que despertam para a dimensão lúdica na utilização do jogo como uma forma inovadora no ensino da Filosofia, e sobre o ensino a partir do contexto catarinense, atingindo e expandindo-se a outros níveis.

Discute-se os conteúdos apresentados no Currículo Base do Ensino Médio do Território Catarinense, noções de inovação na composição de seu inventário teórico, seus temas filosóficos, conceitos, objetivos, competências, habilidades, planejamento didático e plano de aula executado em sala de aula. Objetiva-se com esta pesquisa vislumbrar avanços ou fatores limitantes, promover o debate e a discussões, a fim de se chegar à esclarecimentos acerca da influência da inovação no ensino de Filosofia, para os anos finais da educação básica.

A finalidade consiste em contribuir para formar jovens bem preparados, qualificados, críticos para o exercício da cidadania, éticos ao mercado de trabalho e de suas futuras profissões. A partir de leituras, estudos de documentos, formação continuada e cursos de capacitação, a pesquisa apresenta várias concepções de inovação no ensino da Filosofia para a Educação Básica, aponta as contribuições e reflexões de importantes autores do referencial teórico, para a utilização da inovação na melhoria do ensino e a aprendizagem em Filosofia, apresenta importantes reflexões nos registros de práticas educacionais e programas inovadores, demonstra a satisfação de professores e estudantes na execução de atividades integrais e inovadoras no ambiente escolar e na sala de aula. Assim, a articulação de atividades inovadoras amplia os valores intelectuais no capital humano: o estudante, desafiando-os a assumir novas responsabilidades frente aos desafios educacionais do século XXI, no ensino de Filosofia, na área de Ciências Humanas.

\section{Metodologia}

A pesquisa propõe-se, de maneira teórica e bibliográfica, discutir criticamente pensamentos já existentes e apresentados em sua constituição. Isso se constituirá mediante o domínio dos conceitos fundamentais, presentes no referencial 
bibliográfico, para promover a reflexão, proporcionar o crescimento e o aprofundamento científico com relação ao tema abordado, com o intuito de construir e contribuir na busca do conhecimento filosófico.

Conforme Michel (2015), a análise qualitativa fundamenta-se nas ciências sociais, uma vez que se ampara em avaliações, na consistência de dados e termos, referendando a importância de análises consistentes, debates e reflexões aprofundadas pelas pesquisas qualitativas, trazendo à tona a verdade pela dinâmica da experimentação, fazendo contraponto aos números e estatísticas que apenas fazem a medição da realidade, e em muitos casos não provocam mudanças e transformações significativas, ao invés de ficar apenas no papel. Nesse modelo de pesquisa qualitativa, o pesquisador participa ativamente, busca compreender e interpretar os dados coletados.

Por meio de técnicas de coletas de documentos, constituem-se como objeto de análise da presente pesquisa: a Base Nacional Comum Curricular (BNCC), Propostas Pedagógicas, Currículos, leis, normas, portarias, decretos, pareceres, resoluções, ofícios, boletins informativos, livros, cadernos pedagógicos, sites e portais eletrônicos, disponibilizados pela Secretaria de Educação e Desporto de Santa Catarina (SED/SC). Além disso, constituem as principais noções de inovação na literatura científica e nos documentos orientadores da SED/SC, com relação ao ensino na disciplina de Filosofia.

A pesquisa documental proporciona informações úteis para o objeto da pesquisa, entendimento, análise e soluções para o problema. Em conformidade com Michel, a pesquisa documental amplia "as informações sobre o objeto de interesse e em função da importância que o mesmo terá para a análise e interpretação dos dados da pesquisa" (2015, p. 83). O corpus documentalium é formado pelo conjunto de textos submetidos à análise. Nesse caso, o pesquisador precisa estar consciente de que, ao examiná-lo e ao analisá-lo, é influenciado por todo esse conjunto de vozes, sempre organizando suas leituras a partir de seus próprios referenciais. Analisar os materiais implica em entender o contexto no qual eles foram produzidos, e que envolve sempre a subjetividade de quem os analisa, mantendo a qualidade, o rigor, a profundidade e o comprometimento na análise do pesquisador.

A partir do objeto de pesquisa, isto é, a partir do entendimento da influência da inovação para o ensino de Filosofia e do entendimento de seu problema, recorre-se a uma análise dos documentos relacionados ao ensino, bem como a aplicação das concepções de inovação relacionadas ao ensino da Filosofia no estado de Santa Catarina. Estes documentos fazem parte da natureza legal, política e educacional, no amparo à produção e ao direcionamento do ensino e da aprendizagem do estado. Utilizou-se da triangulação de dados, por meio da qual realizou-se reflexões sobre os dados coletados com análise detalhada, embasada nas teorias de fundamentação da pesquisa, documentos e práticas metodológicos de ensino, em especial da Filosofia e das Ciências Humanas.

Conforme Michel (2015, p. 83), "a escolha do tipo de documento a ser consultado será feita com o propósito de ampliar as informações sobre o objeto de interesse em função da importância que o mesmo terá para a análise e interpretação dos dados da pesquisa". Formalmente, busca-se nos documentos de ensino no Brasil e em Santa Catarina, aprofundar as implicações do conceito de inovação para o ensino da Filosofia, aprendizagem e produção do conhecimento. Trabalha-se o corpus documentalium sobre o ensino de Santa Catarina, entre os anos 1980 a 2020, com uma leitura crítica, com o objetivo de identificar características do texto, inferindo com o conceito de inovação. Moraes \& Galiazzi (2006, p. 122) apresentam a análise textual discursiva como uma metodologia de análise de dados e informações de natureza qualitativa, com a finalidade de produzir novas compreensões sobre os fenômenos e discursos, "[...] representando um movimento interpretativo de caráter hermenêutico".

Para tal, é importante manter um rigor metodológico como se preparar previamente e retomar às anotações das aulas; selecionar apontamentos; definir instrumentos eficazes para a pesquisa e fazer a triagem de ideias para compreender e dominar os conteúdos. Dessa maneira, as atividades de estudo e pesquisa exigem dinâmica e criatividade para superar obstáculos e acompanhar seu ritmo de evolução e de produção cultural, e da própria ciência. Seguindo a ideia do autor, desenvolveu-se o 
processo básico de leitura, análise e interpretação dos textos: $1^{\circ}$ análise textual; $2^{\circ}$ análise temática; $3^{\circ}$ análise interpretativa; $4^{\circ}$ problematização e $5^{\circ}$ síntese (SEVERINO, 2007).

Conforme Severino (2007), para ter eficácia no estudo e na aprendizagem, na área do conhecimento, faz-se necessário uma contínua e progressiva assimilação dos conteúdos, por sua vez qualitativa e seletiva frente à diversidade das áreas de busca do saber contemporâneo. Além disso, torna-se importante, como método, a documentação no estudo próprio e pessoal do pesquisador, bem como o desenvolvimento da prática documental, a documentação por temáticas e especificidades sobre o objeto de estudo, complementando com a documentação bibliográfica da pesquisa. Tais documentos classificados formam um inventário e um conjunto de textos ligados à área de interesse de estudo do pesquisador. Assim, foram elencadas as etapas seguidas durante a pesquisa, com o objetivo de desenvolver as influências da inovação no ensino da Filosofia.

\section{Documentos Oficiais de Ensino em Santa Catarina - SC}

Busca-se, aqui, contextualizar a partir de alguns documentos educacionais, tais como: Propostas Curriculares, Currículo Base, Cadernos Metodológicos de ensino de Santa Catarina e sua abordagem das noções de inovação para o ensino de Filosofia em SC. Para tanto, é necessário contextualizar o surgimento da Proposta Curricular de Santa Catarina, a qual se desenvolveu a partir de um modelo coletivo de estudo e diálogo entre Secretaria de Estado da Educação e do Desporto e o magistério catarinense.

Verifica-se, inicialmente, que a sua produção segue o movimento de discussão curricular ocorrida no país entre as décadas de 1980, 1990, 2000, e no decorrer do século XXI (Santa Catarina, 1999), apresentando as demandas educacionais e curriculares presentes em cada período histórico, bem como os desafios do século XXI com a PC/SC (Santa Catarina, 2014), Base Nacional Curricular Comum - BNCC (Brasil, 2018) e Currículo Base do Ensino Médio do território catarinense (Santa Catarina, 2020). A integração e alinhamento das políticas educacionais em âmbito estadual e nacional com seus avanços e impasses constituem-se como pilares inovadores para o desenvolvimento da pesquisa.

Constata-se em 1983 a realização de debates, reflexões e discussões na educação em SC, com a participação principalmente dos educadores da rede pública estadual. Realizou-se o congresso estadual no município de Lages, em outubro de 1984. Nesse momento, decidiu-se pela democratização da educação e fez-se uma análise crítica às propostas de ensino até então desenvolvidas, indicando a necessidade de buscar novos referenciais, em perspectiva crítica, contextualizada e moderna, retomando o processo de ensino e aprendizagem, com base em uma nova fundamentação. Desse processo, originou-se a proposta do Plano Estadual de Educação (PEE) para o período de 1985/88, dando origem a um processo sistemático de estudos e discussões entre os anos de 1988 a 1991, o que resultou na primeira versão da Proposta Curricular do Estado de Santa Catarina (Santa Catarina, 1999).

Já no ano de 1985, a discussão educacional fundamentou-se nas questões curriculares, com destaque para a reflexão de textos de cunho social, a fim de despertar e repensar da educação brasileira. Estes textos inseriram o pensamento Materialista Histórico-Cultural da escola Soviética, com textos de Antônio Gramsci (1891-1937) e outros autores da mesma vertente teórica de pensamento, sendo alguns pensadores brasileiros (Santa Catarina, 1999). Neste sentido, salienta-se uma forte aproximação entre educação e política. O intuito era estabelecer critérios e parâmetros para promover uma educação inclusiva das camadas populares, com vistas a traçar novos caminhos para a criação da autonomia e criar uma nova hegemonia aos interesses, buscando valorizar o acesso à educação a todos. A elaboração da Proposta Curricular de Santa Catarina enfatiza, em sua reflexão principal a constituição de um novo modelo de ser humano que se pretende formar no estado, a fim de construir um novo e melhor modelo de sociedade. A partir da escolha para o modelo de ensino implantado, bem como do método e da maneira na compreensão e provocação da relação entre ser humano e a construção do conhecimento. 
A Proposta Curricular de 1991 é resultado de uma construção coletiva de educadores, visando o aprofundamento de seus pressupostos teórico-metodológicos e sua consolidação na prática pedagógica. Seu eixo norteador é a elaboração de um currículo escolar com foco no que se quer ensinar, e propor um consenso em termos de concepção de sociedade que se deseja construir no estado de Santa Catarina.

Já a Proposta Curricular de 1998 teve um processo iniciado a partir de 1995, com um aprofundamento de discussão e a consolidação da relação teórico/prática com a Teoria da Atividade e do Materialismo Histórico-Cultural, o que promoveu a incorporação de temáticas transversais, a fim de superar lacunas constituídas ao longo da história da educação catarinense. Destaca-se, nesse contexto, a realização do Congresso Internacional de Educação, em dezembro de 1996, no qual foram realizadas amplas discussões, com a finalidade de fundamentar a Proposta Curricular e todo o processo de ensino e aprendizagem, a partir da pedagogia Materialista Histórico-Cultural. Esta edição foi elaborada por um Grupo Multidisciplinar e teve sua publicação em 1998.

No período de 1999 a 2003, constituiu-se outro momento de produção de materiais, que resultaram na publicação, no ano de 2000, dos Cadernos: a) Tempo de Aprender: subsídios para as classes de aceleração de aprendizagem nível 3 e para toda a escola (Santa Catarina, 2000a); b) Diretrizes da Organização da Prática Escolar na Educação Básica: ensino fundamental e ensino médio (Santa Catarina, 2000b); c) Tempo de Aprender: caderno do aluno - $\mathrm{n}^{\circ} 3$ (Santa Catarina, 2000c). Além desses, há também os fascículos denominados: 'Proposta Curricular de Santa Catarina: síntese teórica e práticas pedagógicas', com destaque para a consideração de todos os seres humanos como sendo capazes de aprender, compreender as relações e interações sociais estabelecidas pelas crianças, adolescentes e jovens na apropriação e construção do conhecimento, com respaldo à consciência da responsabilidade ética da escola, da família, do estudante com a sua aprendizagem, tendo-os como interlocutores nas interações sociais de todos os entes envolvidos (Santa Catarina, 1999).

No período de 2003 a 2005, deu-se um passo significativo ao processo de discussão, sistematização e socialização da Proposta Curricular de 2005. O fato novo foi a abertura das bases de dados e informações para todas as pessoas. Isso só foi possível por meio da revolução das tecnologias e dos sistemas de comunicação, o que possibilitou aos seres humanos desenvolver novas capacidades de produzir, gerar e distribuir conhecimento em nível local, regional, estadual, nacional e mundial. Esse fato também possibilitou novas reflexões críticas, elaboradas no contexto da realidade e gerou inovações que melhoraram o mundo e suas interações nas vivências cotidianas. As pessoas aprenderam a transformar o seu cotidiano a partir das vivências universais (Santa Catarina, 2005).

Formaram-se Grupos de Trabalho que produziram, a partir do eixo norteador da proposta, cadernos voltados à educação e à infância, alfabetização com letramento, educação e trabalho, educação de trabalhadores, ensino noturno e educação de jovens, servindo como referencial teórico e metodológico para a ação pedagógica nas diferentes etapas e modalidades da Educação Básica, com o objetivo de elaborar e socializar um novo documento norteador, incluindo temas multidisciplinares considerados relevantes nessa fase histórica (Santa Catarina, 2005).

Entre os anos de 2013 a 2014 percebeu-se o surgimento de novas demandas educacionais e curriculares que ocorreram a partir da homologação, pelo Ministério da Educação, das novas Diretrizes Curriculares Nacionais para a Educação Básica, Educação Infantil, Ensino Fundamental, Ensino Médio, Educação Profissional Técnica de Nível Médio, Educação de Jovens e Adultos, Educação Especial, Educação do Campo, Educação Ambiental, Educação e Direitos Humanos, Educação Indígena, Educação Afrodescendente e Quilombola, Educação e Prevenção, Educação Fiscal, Educação para o Trânsito, Educação Nutricional e Alimentar (Santa Catarina, 2000a), tornando necessária a atualização da Proposta Curricular de Santa Catarina com o intuito de agregar ao currículo as novas demandas oriundas das respectivas diretrizes.

Nesse aspecto, a Secretaria de Estado da Educação assumiu a responsabilidade de promover esse novo movimento com os educadores do estado, a fim de construir coletivamente novos pressupostos e a atualização constante da PC/SC e do 
currículo base do território catarinense para o ensino. Ampliando seu inventário teórico e documental dentro do avanço e constituição de novas noções inovadoras para o ensino. Independente de cada período abordado anteriormente é possível perceber diferentes noções de inovação e atualização dos documentos norteadores.

Para tanto, identificou-se o papel das Ciências Humanas para a

[...] criação de condições para que os estudantes desenvolvam competências que lhes permitam analisar, compreender e posicionar-se diante da realidade política, econômica, social, cultural e religiosa em que estão inseridos, bem como a compreensão da complexidade do mundo atual e seus reflexos na vivência e nas práticas do estudante, para o que contribuem significativamente os conceitos da Sociologia em suas diferentes correntes sociológicas (Santa Catarina, 2014, p. 147-148).

Percebe-se, também, a importância da Filosofia e das Ciências Humanas para o desenvolvimento e a apropriação de conceitos filosóficos no processo de ensino e aprendizagem. Entre eles, é importante mencionar os conceitos relacionados às influências da inovação, como o uso da inovação para a indústria, suas tecnologias e seu desenvolvimento científico na contribuição para o desenvolvimento da sociedade industrial e a implantação de uma cultura tecnológica e inovadora.

Para tanto, conceitos como ideologia, cultura, relações sociais e modos de produção, meios de comunicação, tecnologias, massificação, alienação, produção de cultura, cultura popular e erudita, material e imaterial, indústria cultural [...] diversidades, virtualização das relações sociais, trabalho humano, inovação industrial, tecnológica e científica, sociedade industrial, desenvolvimento regional, economia e mercado, meios de produção e divisão do trabalho, meio ambiente e sustentabilidade auxiliam os estudantes nesse processo de elaboração conceitual (Santa Catarina, 2014, p. 147-148).

É com a intenção de melhorar a aprendizagem dos estudantes que se pensa em inovação. Com a responsabilidade dos entes educacionais, nesse caso a Secretaria de Estado da Educação "reuniu os profissionais da educação diretamente envolvidos com o currículo dos cursos de Ensino Médio [...], com a finalidade de discutir e propor encaminhamentos teóricos e metodológicos para a prática pedagógica em sala de aula" (Santa Catarina, 2012, p. 5). Pois é na sala de aula que o professor concretiza e executa seus planos de aula amparado ou não pelos aspectos inovadores promovidos pelos gestores responsáveis pela educação.

O objetivo consiste na árdua tarefa de despertar o comprometimento dos educadores e dos estudantes no processo de ensino e aprendizagem. Precisa-se avaliar e tomar ciência dos desafios presentes na sala de aula e no processo de ensino. Melhorar a educação e a aprendizagem dos estudantes, apresentando-lhes caminhos novos para a superação do senso comum e a formação de juízos críticos. Com o intuito de agregar novos valores intelectuais aos estudantes na fase de formação, preparando-os para o mercado de trabalho e na vivência coletiva em sociedade.

Schultz, destaca a ideia de "capital humano onde ela consistente em 'capital configurado na criança', que pode ser a chave de uma teoria econômica da população" (1973, p. 9), a qual transfere para a educação a responsabilidade em preparar e qualificar o jovem para o mercado de trabalho, uma vez que "a formação 'capital configurado na criança' pelo lar, pelo marido e pela mulher começaria com a criação dos filhos e prosseguiria ao longo de sua educação por todo o período da infância", ou seja, para toda a vida, conforme a BNCC (2018) e o Currículo de SC (2020), despertando um novo modelo de ensino com "uma abordagem de investimento relativamente ao crescimento da população, acha-se, atualmente, trilhando um novo caminho", conectado com as mudanças da sociedade e da educação brasileira.

Segundo o Caderno Pedagógico de Filosofia, é importante mencionar à relevância teórica produzida ao longo da histórica da educação em Santa Catarina. Tal contexto promove a legalidade para a prática pedagógica em sala de aula e a construção de um referencial teórico-metodológico da Proposta Curricular de Santa Catarina e os documentos do ensino como fonte de reflexão e planejamento dos tempos e espaços curriculares voltados à educação integral dos adolescentes e jovens catarinenses do Ensino Médio, apresentando-se como sendo uma proposta de ensino inovadora (Santa Catarina, 2012). 
Diante dessa realidade, os professores necessitam constantemente avaliar e refazer seus planos de ensino.

Caro professor, trazemos esse documento para sua consideração quando do planejar e do fazer curricular, vinculados aos interesses, às diversidades, às diferenças sociais dos estudantes e, ainda, à história cultural e pedagógica de sua escola. [...] Assim sonhamos a educação que nos transformem em sujeitos críticos e cientes de nosso papel na transformação do mundo (Santa Catarina, 2012, p. 5).

São necessárias novas respostas aos constantes desafios e mudanças sociais, dando ênfase à importância do ensino da Filosofia para a formação do ser humano (Chaves, et al., 2020). Conforme as diferentes formas de linguagem expressas no material, o ensino sem inovação poderá induzir a uma razão estagnada, dogmática e ultrapassada.

Conforme Schultz, quando "[...] atém ao investimento no campo da educação formal, minha esperança é que seja inteligível aos que tomam decisões em tais espécies de investimentos, sejam estudantes, pais de estudantes, professores, dirigentes acadêmicos ou repartições públicas” (1973, p. 9), para promover mudanças significativas na educação para a formação do capital humano e intelectual, atuantes na transformação, melhorando a educação e a sociedade.

Busca-se a criação de modelos sistematizados que ajudam na compreensão dos fenômenos e das estratégias de ensino que permitem problematizar e estabelecer "diálogos entre os componentes curriculares, que ora leva a uma perspectiva científicotecnológica, ora alcança o âmbito sociocultural", proporcionando, assim, uma "produção histórica de inovações científicas e de seus impactos, desde processos que alteraram a dinâmica produtiva, [...] até a nova gama de produtos" a serem comercializados (Santa Catarina, 2014, p. 166).

Conforme analisa Schultz, "investimentos, educação financeira, preparação cidadã e para a qualificação ao mercado de trabalho [...]" criam um pioneirismo em "novas fases do desenvolvimento da população economicamente, socialmente e culturalmente, para a iniciação profissional e ao trabalho profissional a ser desenvolvido por ele no momento presente, angariando novos valores futuros" (1973, p. 9). Despertando nos jovens o interesse em ampliar seus conhecimentos que irão servi-los em cada fase de sua vida, proporcionando-lhes melhores salários e condições de vida.

Ainda, de acordo com Pessoa, "a importância da inovação para a sustentabilidade das organizações já não mais é questionada" (2018, p. 72), a presença da inovação é algo naturalizado para a busca de novas soluções aos desafios do século XXI. Para tanto, a educação torna-se um dos núcleos de criação e desenvolvimento da inovação por meio de investimentos, estudos e pesquisas nos mais diferentes campos e áreas de atuação e de conhecimento promissor.

Para tanto, torna-se importante referir algumas influências e concepções de inovação trazidas pelos cadernos norteadores do Ensino Médio Integral em Tempo Integral e perceber as suas contribuições no processo de ensino, com o intuito de apresentar algumas noções e aspectos inovadores para a educação. O que se pretende é paradoxalmente confrontar antigos modelos, práticas de ensino conservadoras e tradicionais com novas práticas inovadoras de ensino, com a finalidade de atender as demandas e os desafios no ensino estadual e nacional.

\section{Modelo de Ensino Médio Integral e Inovador}

Intenciona-se, neste momento, apresentar a coleta de dados qualitativos e bibliográficos, ou seja, relatar a partir dos Cadernos do Ensino Médio Integral em Tempo Integral, as concepções de inovação, tal como as novas propostas de ensino a serem desenvolvidas no estado de SC. O grande desafio é a superação do descompasso existente entre o que a escola tem para oferecer, com os desejos, anseios e necessidades dos estudantes que apresentam desinteresse pelo ambiente escolar e pelo estudo, causados, muitas vezes, pelos conflitos que permeiam a vivência dos adolescentes no ambiente onde vivem, deixandoos sem perspectivas futuras. 
Com a aprovação da Lei 13.415, de fevereiro de 2017, o Ministério da Educação propôs a reforma do ensino médio no Brasil, com a perspectiva de que o estudante possa entrar no mundo do trabalho, bem preparado, permanecendo mais tempo na escola, com mais horas de convivência e de estudo, e tenha uma formação integral e inovadora (Brasil, 2017). O estado de Santa Catarina, no ano de 2017, iniciou os trabalhos com o Ensino Médio Integral em 15 escolas. Os responsáveis pela formação dos professores, gestores e implementações do novo modelo de ensino amparado no currículo do Programa Educação Integral em Tempo Integral (Pro-EMITI), e Ensino Médio Inovador (EMI), juntamente com as equipes das Gerências Regionais de Educação - GEREDs), hoje Coordenadoria Regional de Educação de Seara (CRE), o Instituto Ayrton Senna, o Instituto Natura (IN), em parceria com a Secretaria de Estado da Educação (Santa Catarina, 2017).

Dessa forma, torna-se importante possibilitar ações que visam conduzir os seres humanos a desenvolver e aperfeiçoar suas formas de linguagem. Ampliar a buscar conhecimentos para sua própria compreensão do meio social onde estão inseridos. Desperta-se, nesse ponto, para a importância do professor enquanto alguém que motiva e cumpre seu papel de mediador entre o conhecimento e seus alunos em sala de aula, trazendo sempre práticas de inovações, bem como uma pluralidade metodológica, inovadora para melhorarem o ambiente (escola, sala de aula) de ensino e aprendizagem.

Hora de decidir o que realmente será feito, retomar a importância das ações anteriores para qualificar as escolhas. É papel do professor estimular os estudantes a fazerem a escolha a partir de conhecimentos e competências trabalhados ao longo do processo como a inovação, a conexão entre ideias, o raciocínio lógico, a compreensão e análise, a argumentação, o uso da linguagem, a valorização das diferenças, dentre outras (Santa Catarina, 2017a, p. 81).

Para tanto, apresentam-se ideias, argumentos e influências entre inovação, ensino integral, sustentabilidade, empreendedorismo e capital humano em Santa Catarina, a partir da BNCC, PC/SC e do Currículo Base do Ensino Médio do Território Catarinense. Busca-se compreender o papel de cada agente no processo de ensino da Filosofia, com relação às Humanidades para a apropriação do conhecimento, do desenvolvimento, dos reflexos dessa relação na atualidade e para encontrar caminhos por intermédio da Filosofia para a formação de seres humanos e de uma sociedade democrática (Padova et al., 2020).

Analisam-se, ainda, os mais diferentes conceitos relacionados à cultura, a diferentes práticas e contextos sociais, a modos de interações apresentadas pelas diversas realidades trazidas pelos estudantes em sala de aula. É importante que a escola perceba essa diversidade cultural, trabalhe nela como fator de enriquecimento para a construção dos estudantes como seres humanos, garantindo o direito à educação, à diferença, o acesso às tecnologias, a inovação e a formação integral do sujeito, com a finalidade de impulsionar a superação de monoculturas, etnocêntricas, dogmáticas e hegemônicas que determinam os modos de ensino, aprendizagem e do fazer pedagógico das escolas.

É necessário verificar a história da construção de parâmetros curriculares em Santa Catarina, desde a elaboração das primeiras propostas curriculares, na década de 1980, até a última atualização da Proposta Curricular de 2014. É também preciso aprofundar o debate de como as influências inovadoras perpassam os diferentes momentos da história educacional, bem como aspectos relevantes da história nacional, estadual e municipal que afetam diretamente as unidades escolares.

Dessa forma, testemunha-se, ao fazer parte da escola que desenvolveu, desde 2014, a implantação do programa ensino médio inovador e integral. A escola se destaca na ampliação das horas dos estudantes no ambiente escolar, de ensino e aprendizagem, com o desenvolvimento de projetos coletivos e inovadores. Promovendo a ampliação de saberes, competências, habilidades e capital humano com valor intelectual agregado aos próprios estudantes.

Os professores passaram a planejar e refletir nas quintas-feiras as atividades de maneira coletiva, por área do conhecimento, durante cinco horas de planejamento, recebendo como se estivesse em sala de aula. Esse fato melhorou significativamente o ambiente escolar na relação entre professores, estudantes, monitores de recreação e de leitura. Também se 
ampliou o envolvimento das famílias e das comunidades dos estudantes. Ressalta-se que vale a pena investir em modelos de ensino médio inovador em tempo integral, pois a ampliação de políticas públicas dessa magnitude faz com que os jovens aprendam e se desenvolvam técnica e intelectualmente.

Segundo Schultz, “[...] uma informação nova compõe-se de duas partes básicas: (1) a que se transforma em novas capacidades técnicas que, quando adquiridas, são formas de capital humano", agregando novos valores para o mercado de trabalho e, "(2) a que se transforma em novos materiais que, quando realizados, são novas formas de capital não-humano" (1973, p. 18), ou seja, a capacidade do ser humano produzir novos produtos a partir de seu trabalho, angariando recursos para o seu sustento e desenvolvimento.

Conforme López-Ruiz, “[...] 'o humano', um conjunto de habilidades, destrezas e aptidões próprias dos homens, adquire valor de mercado e se apresenta como forma de 'capital' - entendido este como uma soma de valores de troca que serve de base real a uma empresa capitalista" (2007, p. 15). Assim, a educação contribui significativamente para o desenvolvimento humano com habilidades e valores para atender às necessidades do mercado de trabalho, despertando a necessidade de mudanças inovadoras para o ensino, em especial do ensino de Filosofia em Santa Catarina.

Dessa forma, apresentam-se os Princípios da Educação Integral como algo que necessita ser superado por meio de um novo modelo de ensino médio inovador em tempo integral, por sua vez, amparado em bases legais para atender os aspectos paradigmáticos, interdisciplinares, integrais, críticos e inovadores.

Os contextos desafiadores de nosso século também não foram desprezados na formulação dos propósitos de uma educação integral para o século 21. A chamada "sociedade do conhecimento e da inovação" exige que os sujeitos sejam capazes de acessar, selecionar e construir discursos frente a um volume substancial de informações e de conhecimentos disponíveis, interagindo cotidianamente a partir das tecnologias da comunicação e da informação, pensando e agindo de modo crítico diante de questões cada vez mais complexas, elaborando soluções criativas para os problemas e fazendo escolhas consistentes com seus projetos de vida (Santa Catarina, 2017b, p. 14).

Dessa maneira, faz-se necessário utilizar e atualizar novas estruturas curriculares, desenvolver novas metodologias ativas, práticas pedagógicas que tragam a efetivação, a inovação e a integração na implementação de um novo currículo de educação inovadora em tempo integral. Consideram-se importantes os aspectos da formação continuada, da gestão escolar compartilhada e de um novo clima em âmbito escolar por meio do reconhecimento do trabalho pedagógico realizado pelos estudantes, professores, gestores, pais e comunidade em geral (Santa Catarina, 2017d).

Destaca-se a Gestão Escolar e a forma como se articula, sendo "concebido com o propósito de desenvolver um espaço de inovação curricular composto por componentes que possibilitam novas práticas de ensino e de aprendizagem" (Santa Catarina, 2017e, p. 14). Práticas que promovam e ampliam a dialética entre estudantes, incorporando os seus anseios à vida escolar, a fim de promoverem aprendizagens significativas no desenvolvimento de competências e habilidades. Onde estas se tornem importantes para a o progresso da vida no século XXI. Com o objetivo de apontar importantes e novas contribuições para superar os problemas e desafios com criatividade e dinamismo que marcam o ensino médio.

Percebe-se outro aspecto na superação do ensino médio tradicional: para inovar busca-se a introdução de uma nova matriz curricular, oferecendo novos componentes inovadores aos estudantes, novas oportunidades educativas transformadoras, ligadas à construção de projetos de vida, protagonismo, pesquisa, construção do conhecimento a partir do contexto no qual o estudante está inserido, o que demonstra o compromisso com o desenvolvimento das competências cognitivas e socioemocionais importantes para viver no século XXI (Santa Catarina, 2017f).

Essas habilidades podem e devem ser ampliadas ou refinadas, tornando-se ainda mais úteis no sentido de desenvolver o pensamento reflexivo e analítico. Isso, por sua vez, faz do "método científico" uma importante estratégia a ser usada 
no ensino quando o objetivo e desenvolver o raciocínio lógico, o pensamento crítico dos alunos e a inovação ou a geração de conhecimentos próprios (Santa Catarina, 2017g, p. 35).

Para tanto, a contribuição da escola e do professor torna-se fundamental, ao motivar e melhorar as habilidades dos estudantes nos aspectos de criarem novos argumentos lógicos para o exercício da cidadania e da democracia na sociedade atual, buscando assim, certa autonomia e independência na produção de suas ideias, argumentos, pensamento e o seu próprio conhecimento. Nota-se a importância do ensino da Filosofia no Ensino Médio para desenvolver e ampliar tais habilidades dos estudantes, futuros profissionais com raciocínio lógico, coerente e pensamento crítico em pleno século XXI.

Investimentos na educação, formação de estudantes e de professores despertará o interesse e uma absorção melhor no mercado de trabalho. Mas, "para isso acontecer, esses atributos humanos precisam, de certa maneira, ser abstraídos das pessoas concretas que os detêm, das pessoas concretas nas quais existem, e precisam se articular [...] em função de um fim externo a elas" (López-Ruiz, 2007, p. 15). Nesse caso, o fim externo se materializa em trabalho em diferentes profissões, as quais os jovens venham ocupar na sociedade. Isso porque o capital se concretiza não em dinheiro ou materiais, mas em atributos, competências e habilidades humanas, portanto, o capital é investido em seres humanos: os estudantes.

Também vale mencionar a reflexão apresentada por Schultz "[...] a educação organizada produz um punhado de formas diferentes de capital humano de durabilidade variável. A educação de nível superior está empenhada em três tipos de maior calibre de atividades de produção, que implicam descobrir talentos, instrução e pesquisa” (1973, p. 155), com vistas a continuar o desenvolvimento intelectual humano em níveis superiores, a fim de melhorar os aspectos necessários para a qualidade de vida humana e social.

Analisa-se também, segundo Schultz, que "a educação é uma Forma de Capital Humano. É humana porque se torna uma parte do homem, e é capital porque é uma fonte de satisfações futuras, ou de futuros rendimentos, ou ambas as coisas" (1973, p. 155). Assim, a educação promove e busca principalmente soluções dos problemas ligados ao viés econômico por meio dos investimentos realizados na formação e educação do sujeito, além de ampliar o valor intelectual do capital humano, promovendo o desenvolvimento do cidadão com novas competências e habilidades.

É na prática que gestores, professores e estudantes aprendem e ensinam articulados de maneira integradora e inovadora, despertando um novo desejo de ensinar e de aprender, com a formação de uma nova consciência crítica para o exercício da cidadania, por meio do incentivo e dos anseios que os estudantes têm, com expectativas de que os professores mudem o jeito de ensinar, buscando linguagem e métodos mais modernos, atualizados, ajustados aos desafios que se colocam nos dias de hoje (Santa Catarina, 2017a, p. 16).

Segundo Schultz, "[...] ao investirem em si mesmas, as pessoas podem ampliar o raio de escolhas posto a sua disposição. Esta é uma das maneiras porque os homens livres podem aumentar o seu bem-estar” (1973, p. 33), por meio dos investimentos que os estudantes, famílias e governantes promovem na educação e no desenvolvimento profissional, para atuarem no mercado de trabalho. É necessário ter uma visão em que os estudantes são vistos como parceiros e interlocutores no processo de aprendizagem, com conteúdo que thes pareçam úteis para a vida, professores e jovens compartilhando novos 'menus' de ideais e conhecimentos. Nesse sentido,

[...] um espaço flexível e aberto às inovações, que abriga componentes que ampliam o diálogo com as juventudes presentes na escola, a fim de promover as seguintes aprendizagens: aprender a projetar escolhas na vida, aprender a intervir no seu entorno social, aprender a pesquisar e aprender a estudar. Por meio de percursos formativos estruturados a partir da projetificação e da personalização, os estudantes têm a oportunidade de, durante sua trajetória escolar, lidar com o duplo desafio juvenil, que é a construção da identidade e do projeto de vida, contando com a orientação de seus professores (Santa Catarina, 2017a, p. 28). 
Outro aspecto que aparece como um componente inovador é a articulação entre escola, família e trabalho. Fazer saber os modelos de projetos a serem desenvolvidos pela escola, articulados com as famílias ou as comunidades na qual os alunos estão inseridos e, "nesse sentido, é essencial que gestores, professores, estudantes, nas diversas oportunidades de diálogo com as famílias, discutam sobre as expectativas de aprendizagem nos projetos e as relações que estes estabelecem com conhecimento", bem como promover um acompanhamento permanente no desenvolvimento dos jovens enquanto estão na escola (Santa Catarina, 2017a, p. 44).

O Ensino Médio Integral em Tempo Integral e Inovador demonstra a necessidade de ressignificar o trabalho pedagógico nas escolas, inspirado na ideia de trabalho integrado, colaborativo e coletivo, favorecido pelas parcerias compostas para os momentos de planejamento coletivo e por áreas do conhecimento, bem como pelas formações continuadas e em serviço de toda a equipe escolar. A seguir, constam algumas características importantes em relação a atuação aos materiais, planejamentos e propostas integradoras de trabalho:

Planejamento Integrado Comum, Planejamento por Área de Conhecimento, autoconhecimento, abertura para o novo, responsabilidade, comunicação, pensamento crítico, currículo integrado, resolução de problemas, criatividade, protagonismo juvenil, situações desafiantes, problematização, colaboração, matriz flexível, [...], Núcleo Articulador, Projeto de Vida, metodologias integradoras, aprendizagem colaborativa, presença pedagógica, educação por projetos, problematização, multiletramentos, acompanhamento sistemático e intencional, e por fim formação compartilhada (Santa Catarina, 2017h, p. 38).

Um dos fatores importantes é a socialização e trocas de experiências, de aprendizado, debates e viabilização do desenvolvimento e da aprendizagem nas unidades escolares. Esse fato estimulou o interesse em "inovar e trabalhar de forma integrada, criando grupos de trabalho, compostos por profissionais com representatividade de todas as gestões das unidades escolares, com a finalidade de gerenciar as ações e inovações a serem implantadas” (Santa Catarina, 2017h, p. 13).

Aqui, vale referir algumas estratégias de planejamento e acompanhamento das aprendizagens dos estudantes, como "o planejamento integrado; planejamento por área de conhecimento; reunião de avaliação e replanejamento; e reunião de conselho de classe" (Santa Catarina, 2017h, p. 16). Um dos pontos a ser considerado é que

o segredo do sucesso do processo ensino e aprendizagem está no professor, na proposta pedagógica e é na relação professor-aluno-conhecimento que se desenrola a educação [bem como] a criação de um grupo de docentes unidos, motivados e acima de tudo, professores estudantes [Percebe-se também o cuidado com o bem-estar dos professores] Procuramos dar condições de trabalho [...] auxiliando com os materiais necessários para a realização das atividades, suporte tecnológico, priorizamos o espaço físico com salas ambientes [...] (Santa Catarina, 2017h, p. 22).

Fica claro, nesse sentido, que existe uma satisfação ao aceitar o desafio do novo com seus benefícios tanto para professores quanto para alunos, pois "para esse novo ambiente produtivo do século XXI, vê-se que é exigida uma formação que inclui flexibilidade funcional, criatividade, autonomia de decisões, capacidade de trabalhar em equipe, capacidade de exercer múltiplos papéis" (Santa Catarina, 2017h, p. 25), bem como a diversidade na execução de tarefas e atividades na escola e o desenvolvimento de um pensamento com autonomia, crítico, e novas habilidades para resolver problemas.

Destaca-se o modelo de ensino integral e inovador como algo promotor de mudanças e melhorias para aumentar a qualidade do ensino nesta etapa formativa. Conforme aparece nos documentos de Santa Catarina (2017h, p. 2), "a proposta para o Ensino Médio em Tempo Integral adotada pela Secretaria de Educação de Santa Catarina concebe o estudante como sujeito central no processo de aprendizagem [...]", pois o foco do ensino é a aprendizagem do estudante e sua emancipação como sujeito ativo e responsável pela sua aprendizagem.

A frequência do aluno na escola está sempre "desafiando a comunidade escolar a ver o jovem por trás do aluno e a dialogar efetivamente com a juventude múltipla que habita a escola - e não com imagens abstratas, idealizadas ou carregadas 
de estereótipos sobre a condição juvenil" (Santa Catarina, 2017h, p. 29), o que desperta e sensibiliza os jovens para ampliar seu leque de conhecimento, ou seja, saindo do Ensino Médio melhor para assumirem um lugar no mercado de trabalho.

É possível perceber nos depoimentos dos professores a satisfação em assumir e participar dos modelos de Ensino Médio Integral e Inovador, tendo por base os destaques e relatos dos docentes que comprovam a sua satisfação e a dos alunos. A "professora de Matemática, com 26 anos de experiência no magistério, desistiu da licença e se diz reencantada com a educação". Ela prossegue dizendo: "Estava desmotivada pelas condições. [...] Sua forma de ver os alunos também melhorou: "Vejo alunos com ânimo, com vontade de estudar. Isto faz com que a gente se sinta feliz!” (Santa Catarina, 2017h, p. 23).

Outro depoimento importante é "a presença das metodologias em sala de aula faz com que a ideia do 'professor explicador' seja substituída pelo 'professor mediador"”. Percebe-se a mudança no uso de metodologias integradoras e inovadoras no ensino em sala de aula, com o depoimento da professora, para a qual o docente assume a função de mediar o conhecimento. A função "será baseada na interação e na colaboração entre professores e estudantes, por meio [...] de um vínculo que promova o acolhimento, a exigência, o compromisso com a aprendizagem e o desenvolvimento socioemocional de cada estudante" (Santa Catarina, 2017h, p. 101).

Para tanto, viabilizar novos modelos de ensino inovadores e integrais demandam uma continua liberação de investimentos para viabilizar o funcionamento dos mesmos. Na realização dos modelos aqui abordados se percebe a satisfação dos profissionais da educação na atuação em suas escolas. Bem como a satisfação e a motivação dos estudantes e de suas famílias em participar projetos inovadores para ampliar seu conhecimento e preparar suas vidas para ações futuras. Pois, percebe-se a satisfação devido os investimentos realizados em capital humano, que passa a influenciar sobre o capital não humano, motivo de desejo, satisfação e realização. O desafio é criar consciência de políticas públicas para garantir e aumentar os investimentos na educação, onde esses ampliam os conhecimentos, competências e habilidades no capital humano, que a longo prazo melhora as ações pessoais e sociais, diminuindo a necessidade da aplicação de recursos e programas assistencialistas. Apresenta-se em seguida diferentes reflexões em torno da contextualização e do desenvolvimento do pensamento relacionado ao conceito de inovação.

\section{Contextos e Avanços da Inovação}

Para avançar e consolidar a presente pesquisa apresenta ideias de alguns teóricos e pensadores da educação. Com olhar especial voltado para o conceito de inovação no ensino médio catarinense e brasileiro. Principalmente no que se refere ao ensino da Filosofia e das Ciências Humanas em SC. No contexto brasileiro, especialmente no início do século XXI, percebe-se que as escolas recebem inúmeras informações sobre inovações em questões como: recursos tecnológicos, sites, aplicativos, metodologias, planejamentos, planos de curso e de aula, formação continuada de professores, entre outras. Também se percebe a criação de leis no Brasil, que impactam diretamente na educação, provocando mudanças sobre o currículo, passando do modelo de ensino tradicional para um modelo inovador conforme os modelos que vem sendo testados em nível estadual, com a intenção de atender os novos desafios profissionais dos estudantes no século XXI, especialmente para as exigências do mercado de trabalho, investindo em conhecimento no capital humano.

Schultz, em sua obra "O capital humano: investimento em educação e pesquisa" desenvolve e apresenta a teoria do capital humano.

A característica distintiva do capital humano é a de que é ele parte do homem. É humano porquanto se acha configurado no homem, e é capital porque é uma fonte de satisfações futuras, ou de futuros rendimentos, ou ambas as coisas. Onde os homens sejam homens livres, o capital humano não é um ativo negociável, no sentido de que possa ser vendido. Pode, sem dúvida, ser adquirido, não como um elemento de ativo, que se adquire no mercado, mas por intermédio de um investimento no próprio indivíduo. Segue-se que nenhuma pessoa pode separar-se a si mesma do capital humano que possui. Tem de acompanhar, sempre, o seu capital humano, quer o sirva na produção ou no 
consumo. Desses atributos básicos do capital humano, surgem muitas diferenças sutis entre o capital humano e nãohumano, que explicam o comportamento vinculado à formação e à utilização dessas duas classes de capital (1973, p. 53).

Entende-se que é em função dessas duas categorias de capital, a humana e a de não-humana que movem os investimentos. Sejam eles em educação, inovação, empreendedorismo, sustentabilidade, novos modelos de ensino e em especial as influências da inovação no ensino da Filosofia. Assim, o desenvolvimento racional e a produção do conhecimento nos estudantes e futuros trabalhadores recebem uma grande influência da Filosofia, agregando um valor intelectual sempre em renovação e inesgotável, pois, por meio do investimento na busca do conhecimento, os estudantes poderão alcançar níveis melhores de intelectualidades para ampliar o capital humano e de rendimentos econômicos para ampliar o seu capital não humano (Ausani \& Alves, 2020).

Para tanto, seria impossível separar o conhecimento adquirido do ser humano. Entende-se o capital humano como uma soma de valores que serão trocados, para servir ao mercado de trabalho e receber certos valores econômicos em troca, pois poderão ser investidos em atributos humanos, ou em capital não humano para satisfação material. Neste sentido, para Schultz, "o comportamento de consumo da educação é destinado ou ao consumo habitual, satisfazendo o bem-estar do consumidor no momento presente, como o que se refere à alimentação, ou ao futuro, como a aquisição de habitações” (1973, p. 57). Para melhorar sua condição de vida tanto presente quanto futura é importante que o estudante de ensino médio valorize o estudo como meio de conseguir agregar valores humanos e não humanos como um devir em si mesmo, através de seu esforço e dedicação.

Por conseguinte, entende-se que o investimento na educação pode fazer progredir as capacitações das pessoas, melhorando seus futuros salários e rendimentos. Para tanto, destacam-se duas partes: de um consumo futuro e de um componente de futuros rendimentos, ou seja, é pela educação que se percebe o aumento dos rendimentos futuros, aumento da capacidade de consumir e melhorar a qualidade dos produtos consumidos, tanto pessoal, quanto familiar, mantendo a circulação de dinheiro e ampliando suas economias. Diante desse contexto, a seguir, consta um rol de obras e autores preocupados em debater e apresentar ideias que venham a contribuir com este debate e reflexão, além de compor parte do escopo do tema desta pesquisa em refletir as influências da inovação para o ensino da Filosofia na educação básica.

Algumas pesquisas realizadas por Huberman, publicadas em 1973, em sua obra: "como se realizam as mudanças e educação". O autor procura fazer a distinção entre a inovação e uma transformação intencional e deliberada, partindo das relações humanas em relação aos processos de ensino, acarretando a evolução dos próprios objetivos colimados para o desenvolvimento humano. Conforme Huberman, “o próprio conceito de inovação é, de certo modo, conservador, pois a função primordial da inovação é tornar familiar o que não era, é enxertar o novo no velho" (1973, p. 9).

Ora, na educação aparecem as resistências em relação às mudanças, pois estas provocam instabilidade, incertezas e inseguranças frente a busca das novidades, portanto a inovação se manifesta pela capacidade de os indivíduos modificarem o meio em que vivem com a sensação de inovação e evolução nas atividades que realizam. Huberman (1973) ainda salienta que é importante entendermos bem quatro pontos. No primeiro se destaca a capacidade de inovação se manifesta pelos indivíduos, nas instituições e nos sistemas de ensino. Pois, estes criam mecanismos para mantê-los funcionando, experimentando-os para melhorar e inovar, superar resistências, o que já é dado, pronto, acabado e estabelecido como certo, da mesma forma que esses mecanismos vão determinando a reação e a inovação.

Um segundo ponto é entender as condições de uma inovação ser ou não aceita. Nesse sentido, são relevantes as variáveis, como a complexidade da inovação, os custos e valores, sua comunicabilidade, sua divisibilidade, relação entre a fonte de mudança e as pessoas assistidas pela execução da mudança, a compatibilidade entre a inovação e o meio ambiente em que ela está sendo desenvolvida e aplicada. 
No terceiro aspecto é a avaliação da necessidade de mudança dentro do sistema escolar. Nesse caso, a maioria das inovações têm origem externa. Para Huberman (1973, p. 11), "as inovações mais duradouras e mais eficazes são aquelas que o utilizador assimilou, isto é, que ele adotou em razão de the satisfazerem as necessidades específicas", ou seja, mudando e utilizando métodos de ensino antigos, conservadores e tradicionais por inovadores, eficazes, com novas habilidades e competências às mudanças individuais, institucionais e coletivas advindas da base.

Por último, apresenta-se o fator crítico, no qual não é a natureza da inovação em aprimorar o ensino e aprendizado, mas as mudanças que o adotante será obrigado a efetuar pessoalmente. Para Huberman (1973, p. 11), "toda vez que uma inovação importante é proposta, pede-se aos professores e administradores que atuam uns sobre os outros e sobre os alunos". Assim, superar e respeitar questões hierárquicas muitas vezes é motivo de criar resistências a inovação. Para tanto, imprime-se ênfase inicial à mudança de atitudes e somente mais tarde a mudança de métodos e práticas. Promover na base assimilação da necessidade e da implantação de medidas inovadoras.

De acordo com Westley, o termo inovação é altamente traiçoeiro, sendo ao mesmo tempo sedutor e enganoso: "sedutor, porque implica melhoramento e progresso", com a realidade significando alguma coisa de novo e de diferente. Para o autor, é "enganoso, porque desvia a atenção da substância da atividade em causa - o aprendizado - em favor do cuidado da tecnologia da educação" (Westley apud Huberman, 1973, p. 15). Exemplificando: instalar um laboratório de química na escola representa algo novo e diferente, representa mudança. No entanto é preciso distinguir a inovação em si e as inovações que representam as melhorias, sejam elas melhorias estruturais ou de ensino e aprendizado, mas também entender se houve influência da inovação na causa das mudanças e melhorias aplicadas. O autor chama atenção para termos o cuidado de não perder o foco e a atenção no ensino e na aprendizagem em favor do cuidado tecnológico e estrutural de decisões isoladas e individualistas.

De acordo com Gadelha (2019, p. 8), "além do risco de acesso restrito a esses avanços [...] em ciência, tecnologia e inovação sejam apropriados pelas lógicas do capital que não só restrinjam, mas ainda façam desses avanços uma nova forma de expropriação", ou seja, alienação e exploração do capital humano, em nome das tecnologias e da inovação, com um discurso de riqueza e conforto ao ser humano. Contudo, estes, sem condições de discernir sobre necessidades, desejos e vontades pessoais, acabam sendo explorados e excluídos, por não terem acesso aos benefícios sociais, econômicos, culturais, estruturais e uma vida mais humana e digna.

No mesmo sentido, Gadelha $(2019$, p. 8$)$, alerta que "se não houver cuidado, levaremos uma grande massa da população pobre, excluída, a se relacionar com máquinas e com o grande risco de viés, parcialidade, já que essas máquinas e algoritmos estão sendo formatados para atender a interesses econômicos", servindo a grandes conglomerados econômicos, ideológicos, políticos, culturais, e religiosos para alavancar a economia a partir do consumismo desenfreado e sem necessidade, com práticas da descartabilidade, sem consciência sustentável e compromisso ambiental. Conclui o autor: "lógicas que, para o pesquisador, estão no sentido contrário [...] da coletividade. 'Ciência, tecnologia inovação estão aí para servir as pessoas e não se servir das pessoas e isso é muito importante [...]” (Gadelha, 2019, p. 8).

Cria-se, nesse contexto, um sistema de controle cada vez mais alienante, burocrático, autoritário e penalizador do próprio ser humano, que precisa alimentar sistemas com ideias, sonhos, energias, disposição, em que a própria vida acaba passando batida, sem sentido e significado, uma vez que o estado, os grandes sistemas ideológicos, políticos, religiosos, monetários, indústria cultural, comércio se alimentam da energia e das almas humanas.

A inovação, segundo Huberman (1973, p, 17), é, pois, "uma operação completa em si mesma, cujo objetivo é fazer instalar, aceitar e utilizar determinada mudança". Na sequência, o autor refere que "[...] para enquadrar-se no campo da aplicação [...] a inovação deve perdurar, ser amplamente utilizada e não perder as características iniciais. O sistema de ensino frequentemente é tentado a mudar as aparências para não alterar a essência". Entende-se como essencial, nesse contexto, o 
processo de ensino e aprendizagem dos estudantes. Portanto, na educação, a maioria das inovações tem influência direta sobre as relações sociais, sobre a forma de interações estabelecidas entre os entes envolvidos em torno da educação e do contexto em que se encontram a sociedade, a comunidade, o bairro, a família, a escola, os alunos, os professores, o corpo administrativo e as políticas públicas desenvolvidas para atender a demanda educacional.

Todo esse sistema é, para Huberman (1973, p. 17), desenvolvido e gerido a partir do "fato de que as operações do destino são conduzidas por pessoas, que são os instrumentos da transformação", de mudanças e inovação. Isso ocorre não graças a meios materiais técnicos (ferramentas, máquinas, método de exploração), obriga a modificar as atitudes fundamentais quando são modificados os comportamentos ou as competências, mas que os meios técnicos e materiais auxiliam para promover a mudança e a inovação incidindo diretamente sobre o capital humano.

Conforme Gadelha, entre os muitos caminhos a serem seguidos, o importante

é sempre reforçar o caráter humano. A ciência, tecnologia e inovação têm que ser subordinadas a um modelo de sociedade que seja humanizado, pautado pela solidariedade e pela equidade, [...] mas também as estratégias de futuro. Faz parte de uma vida saudável termos projetos de futuro, retomar as energias utópicas que estão tão abaladas no mundo contemporâneo $(2019$, p. 8).

Entende-se, nesse contexto, que a educação desempenha um papel importantíssimo para estabilizar a vida, os projetos e os sonhos dos jovens e futuros profissionais do mercado do trabalho. Portanto, elas influenciam em caráter de busca de conhecimentos, especialização ou em formação continuada, mudanças que envolvem atitudes e comportamentos, desde relacionamento entre colegas, alunos e as metodologias a serem adotadas para inovar seus métodos de ensino em sala de aula.

Na perspectiva de Huberman (1973), as mudanças ocorrem de quatro maneiras: a) mudanças nas dimensões e alcances das operações - precisam de investimentos em espaços, equipamentos e despesas com mão de obra Essa é um tipo de mudança relacionada a questões estruturais; b) mudanças na aquisição de novas competências - trata da reciclagem de professores para colocar em vigor novos programas, ensino por equipe, utilização de laboratórios, voltando-se para uma formação humana e capacitação, utilização de programas, superação do individualismo e o domínio na utilização de equipamentos; c) mudanças nos objetivos - meios de autoinstrução, deixa de transmitir de modo autoritário para torna-se assistente, ou seja, uma atuação enquanto mediador e facilitador dos conteúdos no processo de ensino e aprendizagem; d) mudanças nos valores e na orientação - quando estão em jogo numerosos princípios observados de longa data pelos adotantes, por exemplo, na supressão dos exames ou abandono de alguma instrução religiosa.

Até então alguns aspectos do ensino tradicional com exames, média sete, diários físicos preenchidos a caneta entre outros. Em relação com as mudanças que ocorreram no Estado de SC como a implantação dos programas professor online; estudante online, a retirada dos exames finais, a redução da média final do trimestre da nota sete para seis, o conteúdo e a avaliação não mais por bimestre, por trimestres, mas a partir de 2021 por semestre, além de ofertar ao aluno a recuperação paralela, dos conteúdos/conceitos, notas - registrando-as no planejamento, replanejamento e no sistema online; e a aplicação de novas metodologias ativas (Santa Catarina, 2017). Também, a formação continuada para professores, reformulações e adaptações do Plano Político Pedagógico das escolas com a nova BNCC, a Proposta Pedagógica (2014), o novo Currículo Base da Educação Infantil e do Ensino Fundamental e para o Ensino Médio do Território Catarinense (Santa Catarina, 2013; 2019).

No decorrer da pesquisa, angariou-se a ideia de que o conceito de inovação e ensino de Filosofia se envolve na perspectiva futura, onde as ações dos professores se deparam com suas práticas em sala de aula, com seus métodos de ensino, seus planejamentos, planos de aulas e sua formação docente. O qual se exige dos professores uma atualização e rupturas constantes com às práticas em vigor. Tendo a inovação o centro da ação de mudança planejada e conscientemente aplicada ao ensino e aprendizagem de Filosofia, por meio de novas práticas educativas no contexto da escola, professor e estudantes (Chaves \& Alves, 2019). 
Para Saviani, "dizer que algo é inovador porque se opõe ao tradicional significa aqui não apenas substituir métodos convencionais por outros. Trata-se de reformular a própria finalidade da educação, isto é, colocá-la a serviço das forças emergentes da sociedade" (1995, p. 24). Acredita-se que a razão do fracasso da educação não estava na escola como tal, mas no tipo de escola de que se dispunha. Se ela estaria atendendo às necessidades da classe trabalhadora ou da classe dominante, em que muitas vezes os atributos dados à escola eram imensamente superiores às suas condições e possibilidades em desempenhar sua função social perante a sociedade.

Entende-se que a fase de escola redentora da humanidade situava a educação em termos explicitamente políticos. Aqui, a escola era entendida como um instrumento de transformar os súditos em cidadãos, em que se demonstra a participação política como meio de fortalecer a democracia por meio das potencialidades que a escola poderia desenvolver mediante seus processos educativos, isto é, desenvolver uma escola, uma educação que fosse tolerável aos limites, necessidades e interesses das classes dominantes, ideologicamente prevalecendo e influenciando em uma nova formação social, neoliberal e que atenda aos interesses do capitalismo em formar mão de obra qualificada para a geração de lucros e atender os interesses da iniciativa privada, sendo gerada pela própria escola pública.

Na leitura de Saviani, algumas concepções de inovação se desenvolvem em relação a modelos e finalidades da educação humanista moderna, "a inovação será entendida de modo acidental, como modificações superficiais que jamais afetam a essência das finalidades e métodos preconizados em educação" (1995, p. 29). Neste sentido, inovar será alterar essencialmente os métodos, as formas de educar, cuja preocupação já não é com o que se ensina, mas com a forma de ensinar. Ressalta-se a necessidade de criar novas metodologias para aprimorar o que será ensinado em sala de aula.

Por outro lado, "do ponto de vista analítico, não será propriamente alterar, nem acidental, nem essencialmente. Inovar será utilizar outras formas" (Saviani, 1995, p. 29). Criam-se, nesse sentido, diferentes métodos, ou busca-se uma pluralidade metodológica para viabilizar a aprendizagem de diferentes conteúdos, em diversas disciplinas específicas, sendo ministradas pelos professores em suas diferentes competências e habilidades pessoais. Este poderá ser o grande desejo dos jovens estudantes para continuarem seus estudos, suas capacitações e motivações para uma vida melhor no futuro próximo, médio e de longo prazo. Assim, promove-se um projeto de vida a partir do aprofundamento e do ensino da Filosofia.

Para Saviani, portanto, "novo é o outro. Quer dizer, inovação educacional aos meios convencionais, compõe-se com eles ou os substituem. Deve-se notar que em todos esses casos a inovação é entendida em função do aparelho educacional como tal, sem referência ao contexto" (1995, p. 29). Criam-se diferentes modelos educacionais, considerados inovadores de acordo com as necessidades da sociedade da época, muitas vezes deslocados de seus contextos. Cada modelo educacional cria suas próprias inovações de acordo com as demandas e desafios que são gestados na sociedade e apresentados às escolas, às famílias, aos alunos e ao mundo do trabalho que vai absorvendo diferentes tipos de mão de obras. Os tempos, hoje, mudam e se apresentam de diferentes formas e a educação necessita acompanhar tais mudanças.

Para o estado de SC, ou até mesmo a nível nacional, é importante e urgente que se "entenda que a educação é uma das fontes principais do crescimento econômico depois de ajustar-se às diferenças nas capacidades inatas e características associadas que afetam os rendimentos, independentemente da educação" (Schultz, 1973, p. 58). Entre produzir melhor e mais é preciso adotar tecnologias e instruir o capital humano para a educação, aperfeiçoamento e qualificação para a participação cidadã, o trabalho e a produção. Contudo, deve-se notar que as experiências inovadoras devem proporcionar um salto qualitativo que ultrapassa o significado contido na palavra inovação. Com efeito, as experiências aí enquadradas, mais do que inovar o ensino, intentam colocar a educação a serviço da revolução e emancipação social.

No relatório intitulado "Educação: um tesouro a descobrir", Delors questiona: que educação será necessária para amanhã e para que sociedade? Nesse contexto, há necessidade de um consenso em torno da aprendizagem desejada para os desafios do futuro, a fim de revelar a todos, ao longo de suas vidas, a descoberta de seus talentos individuais e coletivos, uma 
relação entre o material e o espiritual, no desenvolvimento do ser humano. Para tanto, indica que a educação é uma utopia necessária para realização dos sonhos, uma projeção de ganhos futuros, tanto intelectuais como financeiros. O relatório sustenta que a educação exerce o papel de inclusão social e promove o desenvolvimento humano.

Além disso, Delors (2012) apresenta a educação repousando sobre quatro pilares: aprender a conhecer, aprender a fazer, aprender a ser e aprender a viver em conjunto, desenvolve a ideia de que a educação se constitui ao longo de toda a vida do ser humano. Para tanto, apresenta a importância do professor para a realização de utopias, sonhos e perspectivas para o ensino e a aprendizagem. Menciona o papel do político no fomento de opções educativas e de sociedades melhores, emprego e renda, inovações, sustentabilidade, descentralização do poder, orientações para o futuro, entre outros. Por fim, há um destaque às contribuições internacionais: educar para a aldeia global, em uma educação voltada para a igualdade, fraternidade, justiça pública e democrática, desenvolvimento social, um mundo multicultural e sustentável.

Perrenoud (2002) ressalta três elementos que integram a compreensão de situações mobilizadoras de competência. Além de buscar esclarecer o conceito de competência, afirma que, quando se está diante de uma situação nova, procura-se, em primeiro lugar, estabelecer uma prática reflexiva com outra situação que se conhece. Para tanto, percebe-se a necessidade de se manter, constante e regularmente, investimentos para melhorar e qualificar o capital humano e intelectual. A escola é esse espaço de que o jovem tanto necessita e, por isso, é importante manter a formação permanente do professorado, atualizado e com uma pluralidade didática e métodos inovadores para ensino e avaliação.

A escola constitui-se como espaço de sustentação para o jovem se encontrar, se conhecer e se descobrir enquanto protagonista do processo educacional, reconhecendo em si suas potencialidades, competências e habilidades. De acordo com a Base Nacional Curricular Comum - BNCC: "[...] identifiquem perspectivas e possibilidades, construam aspirações e metas de formação e inserção profissional presentes e/ou futuras, e desenvolvam uma postura empreendedora, ética e responsável para transitar no mundo do trabalho e na sociedade em geral" (Brasil, 2018, p. 466), com o objetivo de despertar nos jovens o compromisso e a responsabilidade de sua própria formação, especialmente para o seu sucesso pessoal e profissional.

Nesse sentido, é importante que a escola, conforme a BNCC, "proporcione uma cultura favorável ao desenvolvimento de atitudes, capacidades e valores que promovam o empreendedorismo [...] entendido como competência essencial ao desenvolvimento pessoal, a cidadania ativa, a inclusão social e a empregabilidade" (Brasil, 2018, p. 466). Dentro da condição empreendedora, é necessário que os jovens desenvolvam algumas competências, tais como: criatividade, inovação, organização, planejamento, responsabilidade, liderança, colaboração, visão de futuro, assunção de riscos, resiliência e curiosidade científica, entre outros.

Ainda, segundo a BNCC, entende-se que o "empreendedorismo supõe a mobilização de conhecimentos de diferentes áreas para a formação de organizações com variadas missões voltadas ao desenvolvimento de produtos ou prestação de serviços inovadores com o uso das tecnologias" (Brasil, 2018, p. 479), ou seja, capacitar os jovens que saem do Ensino Médio com condições de atender às necessidades das forças emergentes da sociedade, do mercado de trabalho, da indústria e do comércio. No entanto, corre-se o risco de se transferir para a escola a função de capacitação dos jovens para o mercado de trabalho apenas, eximindo-se a iniciativa privada em fazer novos investimentos na capacitação desses indivíduos, conforme suas demandas e especificidades para atender os diferentes nichos emergentes na sociedade e no mercado de trabalho.

Em um mundo em constantes transformações, os jovens estão lutando por um espaço no mercado de trabalho, com a concorrência e a competitividade presentes em seu cotidiano. Para superá-la, faz-se necessário a qualificação, a capacitação em si mesmos, em suas competências, habilidades e potencialidades, estando aptos a se encaixarem nas vagas de trabalho disponíveis, a fim de suprirem as necessidades do mercado.

Há hoje mais espaço para o empreendedorismo individual, em todas as classes sociais, e cresce a importância da educação financeira e da compreensão do sistema monetário contemporâneo nacional e mundial, imprescindíveis para 
uma inserção crítica e consciente no mundo atual. Diante desse cenário, impõem-se novos desafios às Ciências Humanas, incluindo a compreensão dos impactos das inovações tecnológicas nas relações de produção, trabalho e consumo (Brasil, 2018, p. 568).

Neste cenário, salienta-se a importância das Ciências Humanas, nesse caso a Filosofia, para ajudar os estudantes a refletirem sobre si mesmos e sobre seu papel na sociedade e do mercado de trabalho, especialmente no autocontrole e autogestão econômica, social, cultural, trabalhista, consumista e em suas diferentes interações sociais, com uma consciência ética, crítica, responsável, dialógica, prática e cidadã, frente a si mesmo, ao outro, à natureza, à sociedade e ao amor à pátria. Ainda, de acordo com a BNCC, "analisar os fundamentos da ética em diferentes culturas, tempos e espaços, identificando processos que contribuem para a formação de sujeitos éticos que valorizem a liberdade, a cooperação, a autonomia, o empreendedorismo, a convivência democrática e a solidariedade” (Brasil, 2018, p. 577), são aspectos importantes para melhorar a igualdade, a promoção e a inserção social dos jovens no mundo contemporâneo.

Dessa forma, Carbonell (2002) apresenta a inovação associada às mudanças das escolas e das atitudes dos professores, bem como os projetos de reformas apresentados para o ensino, confrontando as pedagogias progressistas em relação ao ensino tradicional, e as pedagogias e metodologias ativas, modos de ensinar e de aprender, componentes curriculares, projetos educativos, autonomia escolar, participação dentro e fora da escola. Se a situação é inovar, tem algo diferente da anterior, de forma que exige a introdução de certo nível de criatividade para responder a situação no que ela tem de distinto, de inovador, quando comparada com todas as anteriores. Mas não basta saber, é preciso saber e agir, tomar decisão, antecipando os seus efeitos (Santa Catarina, 2017f).

Os processos de mudança e de inovação educacional, segundo Nóvoa (1992), passam pela compreensão das instituições escolares em toda a sua complexidade técnica, científica e humana", o que exige tomadas de decisões seguras para garantir mudanças eficazes no processo de ensino e aprendizagem para a formação de seres humanos preparados para as exigências do mercado.

Por conseguinte, observa-se constantes mudanças no universo do pensamento, e é por meio delas que se propõe uma inovação, um novo trabalho com os temas abordados pela Filosofia, a fim de sugerir mudanças de atitudes e comportamentos diante da construção de conhecimentos pela comunidade científica, modificando assim velhos hábitos de ensino, reproduções filosóficas e enciclopédicas. Segundo Stein, “o que poderia ser diferente no comportamento dos que se envolvem com os autores e os problemas da Filosofia, e que esse deve passar pelo confronto com as comunidades de ciência, e atravessar os diversos ensaios de interdisciplinaridade, [...] podendo garantir a inovação” (2011, p. 92). Assim, os filósofos têm que se perguntar o que resta, ainda hoje, de propriamente filosófico, frente aos desafios da construção da cognitividade, da criatividade e da inovação para o ensino médio integral de caráter inovador. Nesse contexto,

a inovação e a mudança que se pode esperar do contato interdisciplinar entre a Filosofia e a ciências, só pode seguir quando o filósofo sai da sua posição do especialista autônomo. Como sair dessa posição é que deve sempre constituir a intenção básica da inovação na Filosofia. Teremos, certamente, diversas posições filosóficas para indicar essas saídas. Já fizemos a experiência de partir de um conceito central, para a ciência e a Filosofia e descobrimos, no conceito complexo "acontecer", um terreno muito favorável a uma aproximação entre Filosofia e ciência em geral. Outras formas de aproximação da Filosofia com a ciência representaram novas tentativas epistemológicas para superar a autossuficiência do filósofo diante do conhecimento científico, sem suprimir o que já denominamos 'aquilo que constitui o propriamente filosófico' (Stein, 2011, p. 112-113).

Ainda, para fundamentar a produção de conhecimento, será desenvolvida uma reflexão sobre a ruptura de paradigmas e a construção de novos paradigmas, com ênfase ao próprio conceito de ciência normal e de seus momentos de crise. Dessa forma, é possível fazer uma revolução científica e promover o surgimento do novo, dentro de uma estrutura de sociedade já consolidada, perfilando o conceito de inovação com o ensino da Filosofia e das humanidades para o ensino médio em Santa Catarina (Ausani \& Alves, 2019). 
Neste sentido, cabe uma reflexão e conexão entre as disciplinas que se encontram no dia a dia da escola, a fim de concretizar relações e objetivos a serem trabalhados coletivamente no âmbito escolar, bem como suas especificidades e coerências entre as múltiplas formas de aprendizagem. Para Rocha, a Filosofia corresponde a uma "dimensão específica da realidade humana, a das curiosidades que tocam nossas mais densas convenções, assume um lugar sui generis no currículo escolar" (2015, p. 45), fortalecendo o ensino das ciências humanas. Conforme Nussbaum, "é educar humanisticamente e criticamente cidadãos globais, inteligentes e responsáveis que irão defender a democracia e o desenvolvimento humano, com competências para colaborar e cooperar acima das diferenças e das fronteiras, na solução urgente dos problemas mundiais da humanidade" (2015, p. 94). Logo, torna-se necessário superar a educação apenas utilitarista, voltada apenas para o mercado, o lucro e a competitividade, tornando-se empobrecida no que diz respeito ao ensino das artes e das humanidades, especialmente na questão do ensino da Filosofia para superar dicotomias e pragmatismos, e valorizar o humano.

Por conseguinte, aposta-se na articulação entre os conceitos de aprendizagem, criatividade e inovação. Dessa forma, criam-se novas premissas: "sem sujeitos inovadores, não há inovação e, nesse aspecto, a dimensão humana é o fator principal do processo inovador; sujeitos inovadores são criativos". Portanto, prossegue o autor: "criatividade é a condição para inovação; a criatividade é, em boa parte, resultante de processos educativos" (Loures \& Schlemm, 2006, p. 39), fomentados pelas principais instituições como: família, escola, Igreja, trabalho e estado.

A mudança, reforma e modernização são significados e atributos da inovação educativa existente em uma definição bastante aceitável e aceita que define a inovação como um conjunto de intervenções, decisões e processos. Esse fato exige intencionalidade, sistematização, que tratam de modificar atitudes, ideias, culturas, conteúdos, modelos e práticas pedagógicas, presenteando e introduzindo a escola e o sistema educacional "em uma linha renovadora, novos projetos e programas, materiais curriculares, estratégias de ensino e aprendizagem, modelos didáticos e outra forma de organizar e gerir o currículo, a escola e a dinâmica da classe" (Carbonell, 2002, p. 19).

A inovação traz emancipação aos estudantes, qualificando-os da melhor maneira possível para o mercado de trabalho e para a vida profissional e social. Para que a inovação possa prosperar em um sistema de ensino, necessita-se de alguns prérequisitos como o apoio e o incentivo da administração. Segundo Carbonell, "os tempos de inovação e da mudança, a percepções muito distintas por parte da administração, que costuma regular em esquema administrativo e a prazo fixo, e dos professores que requerem ritmos pausados e sem data fixa para evitar a angústia que tanto prejudica seu trabalho e a frustração de ver golpeada uma inovação" (2002, p. 25-26).

Portanto, as inovações têm de ser pensadas, geridas e realizadas autonomamente pelos professores. Qual é, então, o papel do Estado ou de qualquer outro poder público? Seguindo a ideia, o Estado deve adotar medidas básicas e necessárias de política educativa e dotar a escola pública dos recursos necessários para que os professores possam levar a cabo as inovações sobre as necessárias condições de qualidade. Para produzir mais e melhorar a inovação, Carbonell apresenta uma reflexão de Paulo Freire, o qual propõe "converter as dificuldades em possibilidades, por que o conflito faz crescer e por que isso é o mais importante, felizmente, em todos os níveis de ensino existe uma boa parcela de professores e professoras dispostos a trabalhar por uma escola diferente" (2002, p. 30).

Disto pode-se entender que a principal força impulsionadora da mudança são os professores e professoras que trabalham de forma coordenada e cooperativa nas escolas e que se comprometem a fortalecer a democracia escolar. Dessa forma, assumem "um compromisso que seguindo o movimento de baixo para cima, orienta-se para a obtenção de uma educação integral que articula as experiências dos alunos e os problemas sociais reais com a cultura escolar, superando a visão estreita, tecnicista e o academicismo do rendimento escolar" (Carbonell, 2002, p. 30). Nesse sentido, é imprescindível que as administrações sejam mais sensíveis ao reconhecimento e apoio das experiências de base e crie um clima mais favorável para liberdade de implantar práticas inovadoras para a ação docente e a renovação pedagógica. Contudo, frente aos desafios 
colocados na contemporaneidade é preciso pensar a educação integral para a vida, unida às forças sociais, articulando a reinvenção da escola como uma grande rede de significados, para diferentes atores ancorados na vida, no trabalho coletivo, democrático e sustentável para a humanidade.

Horn e Staker (2015) enfatizam que o ensino híbrido traz contribuições e melhorias à educação dos estudantes e à capacitação dos professores, ampliando o acesso à inovação, a partir de relatos e experiência. Dessa forma, estimular os professores na busca de novas formas de atuação em sala de aula, planejando, aliando tecnologias para melhorar o aprendizado dos estudantes a partir da realidade brasileira. Na mesma perspectiva, Bacich e Moran (2018), apresentam algumas possibilidades de transformar as aulas em experiências mais vivas e significativas para os estudantes inseridos no contexto de interação da cultura digital, da sociedade, da política e da escola, de maneira criativa e centrada na autonomia dos estudantes e em seu aprendizado, agora frente às diferentes formas de aprendizado das gerações anteriores.

Este contexto educacional exige dos professores novas habilidades, competências didáticas e pluralidades metodológicas. Esse fato implica em capacitação e gera um novo desafio para a formação dos professores, pautada por uma nova realidade: criativa, reflexiva, crítica, compartilhada, de diversidades, de mídias, de tecnologias, de diversidade cultural, de pensamentos, do currículo, de metodologias e de novas relações pedagógicas coletivas, sustentáveis e democráticas, recontextualizando as metodologias de ensino frente à cultura digital, integrando novas mídias e metodologias ativas. Logo, demanda-se a elaboração de modelos educacionais que sejam inovadores. Assim, para que uma instituição se torne inovadora é preciso transformar os ambientes como sendo mais acolhedores - o conjunto de ecossistemas de ensino-aprendizagem é acolhedor.

O primeiro desafio é o acolhimento e a receptividade para "quem entra em ambientes físicos e virtuais, encontra gestores e docentes competentes e abertos para ajudar a aprender; encontra estudantes engajados em atividades desafiadoras, que os estimulam a participar, compartilhar e evoluir" (Mill, 2018, p. 355). Percebe-se a importância da gestão democráticas, baseadas em competências e profissionalismo, para promover ações estimuladoras e participativas, a fim de alcançar a evolução no processo de ensino e aprendizagem dos estudantes.

O segundo desafio consiste em construir currículos são mais integrados, "interligados: interdisciplinares e transdisciplinares que integram áreas de conhecimento de várias formas [...] são holísticos, com uma visão humanística, sustentável e de competências amplas, com foco na ampliação criativa dos conhecimentos em várias situações e contextos" (Mill, 2018, p. 354-355). Existe a flexibilização em detrimento de um modelo tradicional, estanque, individualista, engessamento dos conteúdos programáticos, tirando a autonomia e a criatividade da escola e do professor no planejamento de suas aulas.

O terceiro desafio centra-se na construção de currículos combinam três processos de forma equilibrada: "a aprendizagem ativa personalizada; a aprendizagem entre pares; e a aprendizagem mediada por pessoas mais experientes" (Mill, 2018, p. 355). Percebe-se, a necessidade: a) adaptação do trabalho pelo ritmo, estilo e situações mais pertinentes detectadas pelo próprio professor e com a ajuda e orientação coletiva dos demais professores, em um trabalho coletivo e interdisciplinar; b) trabalho conectado com diferentes grupos e redes de ensino, para troca de ideias e experiências; c) mediação e apoio pedagógico de uma equipe bem formada e estruturada com materiais, estrutura e autonomia para tomada de decisões e resolução de desafios e problemas da escola e dos estudantes, equipe essa formada por novos professores, orientadores, mentores, tutores, entre outros membros que possam colaborar.

Os currículos demandam flexibilidade para que os alunos possam personalizar seu percurso, total ou parcialmente, de acordo com suas necessidades, expectativas e estilos de aprendizagem e também para prever projetos e atividades significativas de grupos, articulando teoria e prática. Será que os alunos têm consciência e poder para definir e dar a flexibilidade aos currículos, tendo em vista as próprias limitações e responsabilidades sobre seu ensino e aprendizado, uma vez 
que as necessidades do mercado podem não representar os desejos e necessidade dos estudantes? Enfim, a inovação não significa influenciar nas decisões futuras dos alunos, mas capacitá-los para que possam receber e sair do ensino médio com uma formação completa, cidadã e mais humana.

Nestes novos tempos, os estudantes necessitam do amparo da família, primeira mola propulsora, embora muitos a tenham fragilizada por diversos motivos; da escola, o espaço de convivência e de interações com os colegas, visualizam no professor ou nos colegas o amparo e a orientação para seguir realizando seus sonhos e utopias da vida. Neste sentido, o ensino inovador coloca-se como um grande desafio a ser trabalhado em sala de aula. Um possível vislumbramento de um caminho seria trabalhar temas transversais nos currículos, com uma metodologia de design para projetos reais importantes, principalmente para fazer uma nova "configuração da vida, numa relação interdependente dos indivíduos" (Tomazi, 2010, p. 28). Viabiliza-se o autoconhecimento, a percepção de algum significado, relevância e visão de futuro com o apoio de professores/orientadores/mentores, ao trabalhar com projetos de vida dos próprios estudantes, projetando a realização de seus sonhos a partir de seus contextos.

\section{Considerações Finais}

Para tanto, incentivar esse modelo de inovação, para a escola pública, em nível médio, contribuirá com o desenvolvimento dos jovens e suas famílias, dos professores, das escolas e das comunidades para melhorarem seus programas de ensino. Percebe-se a necessidade de inserir no currículo aspectos sobre empreendedorismo e inovação, pois a escola também pode preparar os jovens para serem inovadores, desde o início de sua carreira profissional, criando uma cultura empreendedora em todos os municípios, estados e no país, desde a conclusão da etapa de formação do Ensino Médio, tendo continuidade na formação superior.

Conclui-se que é possível curricularizar o empreendedorismo e a inovação na etapa de formação do Ensino Médio, pois melhora e qualifica os jovens para o mercado de trabalho e o desejo de uma vida futura promissora, possibilitando transformações profundas no ambiente escolar, nas relações pedagógicas e no processo de ensino e aprendizagem. Neste sentido, a articulação inovadora, entre teoria e prática, passa pela criatividade do professor em sua prática pedagógica e sua inventividade em termos de métodos e estratégias de ensino, juntamente com inovação das instituições de ensino e das experiências dos alunos, estimuladas pelo Estado, enquanto responsável pela inovação educacional.

Portanto, deve-se superar as principais defasagens no ensino tradicional, encontrar um ponto de equilíbrio e criar condições para que se instale nas escolas um processo integral e inovador. Sabe-se que são mudanças que demandam tempo e dedicação, bem como investimentos de recursos destinados pelo Estado e órgãos competentes para o desenvolvimento educacional. A saber, a inovação envolve práticas interdisciplinares no contexto escolar, processos de ensino, novas metodologias de ensino, novo desenho curricular, gestão escolar, planejamento pedagógico, uso de tecnologias na educação, avaliações, atuação e formação docentes para os desafios do século XXI (Alves, 2021). Enfim, assim como a inovação, o empreendedorismo, a sustentabilidade, o capital humano e o projeto de vida dos estudantes podem contribuir para o seu desenvolvimento intelectual e humano, agregando valores que ficam depositados neles e que poderão render-lhes benefícios futuros.

\section{Referências}

Alves, M. A. (2021). Bioética e interdisciplinaridade: a relação entre educação e meio ambiente. Revista Teias, 22(65), 73-85. https://doi.org/10.12957/teias.2021.54617

Ausani, P. C., \& Alves, M. A. (2020). Gamificação e ensino: o jogo dialógico como estratégia didática ativa e inovadora. Research, Society and Development, 9(6), e139962736. https://doi.org/10.33448/rsd-v9i6.2736 
Ausani, P. C., \& Alves, M. A. (2019). Hermenêutica, ensino de humanidades e atuação docente. Research, Society and Development, 8(11), e508111434. https://doi.org/10.33448/rsd-v8i11.1434

Bacich, L. \& Moran, J. (2018). Metodologias ativas para uma educação inovadora: uma abordagem teórico prática. Penso.

Brasil. (2018). Base Nacional Comum Curricular. MEC. http://basenacionalcomum.mec.gov.br/images/BNCC_EI_EF_110518_versaofinal_site.pdf.

Brasil. (2017). Constituição da República Federativa do Brasil de 1988. Brasília, DF: Presidência da BRASIL. Lei $n^{o} 13.415$, de 16 de fevereiro de 2017. Institui a Política de Fomento à Implementação de Escolas de Ensino Médio em Tempo Integral. Brasília, DF: Presidência da República. http://www.planalto.gov.br/ccivil_03/_Ato2015-2018/2017/Lei/L13415.htm.

Carbonell, J. (2002). A aventura de inovar: a mudança na escola. Artmed.

Chaves, N. C. R., \& Alves, M. A. (2019). Natureza da filosofia e formação da subjetividade: proposta teórico-metodológica para o ensino de filosofia. Research, Society and Development, 8(5), e2785981. https://doi.org/10.33448/rsd-v8i5.981

Chaves, N. C. R., Cheiram, M. C., Zucolotto, M. P. da R., \& Alves, M. A. (2020). Ensino e aprendizagem: educação como encontro inter-humano em Rogers e Morin. Acta Scientiarum. Education, 43(1), e48181. https://doi.org/10.4025/actascieduc.v43i1.48181

Delors, J. (2012). Educação: um tesouro a descobrir. (7a ed.), Cortez; Unesco.

Gadelha, C. A. G. (2019). Os desafios de uma tecnologia que sirva ao humano e não que se sirva do humano. Revista IHU On-line, 544, 8-16. www.ihu.unisinos.br

Horn, M. B. \& Staker, H. (2015). Blended: usando a inovação disruptiva para aprimorar a educação. Penso.

Huberman, A. M. (1973). Como se realizam as mudanças em educação: subsídios para o estudo do problema da inovação. (2a ed.), Cultrix.

López-Ruiz, O. J. (2007). Os executivos das transnacionais e o espírito do capitalismo: capital humano e o empreendedorismo como valores sociais Azougue.

Loures, R. C. R. \& Schlemm, M. (2006). Inovação em ambientes organizacionais: teorias, reflexões e práticas. Ibpex.

Michel, M. H. Metodologia e pesquisa científica em ciências sociais: um guia prático para acompanhamento da disciplina e elaboração de trabalhos monográficos. (3a ed.), Atlas, 2015.

Mill, D. (2018). Dicionário crítico de educação e tecnologias e de educação a distância. Papirus.

Moraes, R. \& Galiazzi, M. C. Análise textual discursiva. Unijuí.

Nóvoa, A. (1992). Os professores e a sua formação. Dom Quixote.

Nussbaum, M. C. (2015). Sem fins lucrativos: por que a democracia precisa das humanidades. WMF Martins Fontes.

Padova, L. C.; Cenci, M. P. \& Alves, M. A. (2020). Formação docente na área da Filosofia. Disciplinarum Scientia. Série Ciências Humanas, $21,269-288$. https://periodicos.ufn.edu.br/index.php/disciplinarumCH/article/view/3268/2711\#

Perrenoud, P. (2002). As competências para ensinar no século XXI: a formação dos professores e os desafios da avaliação. Artmed.

Pessoa, M. L. (2018). Pinceladas de inovação. Curitiba: Vitória Gráfica.

Rocha, R. P. (2015). Ensino de Filosofia e currículo. (2a ed.), UFSM.

Santa Catarina (1998a). Lei Complementar n ${ }^{\circ}$ 170, de 07 de agosto de 1998. Dispõe sobre o Sistema Estadual de Educação. Alesc.

Santa Catarina (2005). Secretaria de Estado da Educação, Ciência e Tecnologia. Proposta Curricular de Santa Catarina: Estudos Temáticos. IOESC.

Santa Catarina (2013). Resolução CEE nº 183, de 19 de novembro de 2013. Florianópolis: Conselho Estadual de Educação.

Santa Catarina (2013). Secretaria de Estado da Educação e do Desporto. Caderno Pedagógico de Filosofia. COGEN.

Santa Catarina (1999). Secretaria de Estado da Educação e do Desporto. Diretoria de Ensino Fundamental. Considerações sobre Diretrizes Curriculares Nacionais - DCNs, Parâmetros Curriculares Nacionais - PCNs, Proposta Curricular de Santa Catarina - PC/SC. IOESC.

Santa Catarina (2017b). Secretaria de Estado da Educação e do Desporto. Instituto Ayrton Senna. Princípios da Educação Integral. SED/IAS (Coleção Educação Integral no Ensino Médio, Caderno no 2).

Santa Catarina (2017d). Secretaria de Estado da Educação e do Desporto. Instituto Ayrton Senna. Avaliação e Aprendizagem. SED/IAS (Coleção Educação Integral no Ensino Médio, Caderno nº 4).

Santa Catarina (2017g). Secretaria de Estado da Educação e do Desporto. Instituto Ayrton Senna. Ciências da Natureza. SED/IAS (Coleção Educação Integral no Ensino Médio, Caderno n ${ }^{\circ}$ ).

Santa Catarina (2017e). Secretaria de Estado da Educação e do Desporto. Instituto Ayrton Senna. Gestão Escolar: núcleo articulador. SED/IAS (Coleção Educação Integral no Ensino Médio, Caderno n 11).

Santa Catarina (2017f). Secretaria de Estado da Educação e do Desporto. Instituto Ayrton Senna. Matemática. SED/IAS (Coleção Educação Integral no Ensino Médio, Caderno no ${ }^{\circ}$ ). 
Research, Society and Development, v. 10, n. 8, e34310817452, 2021

(CC BY 4.0) | ISSN 2525-3409 | DOI: http://dx.doi.org/10.33448/rsd-v10i8.17452

Santa Catarina (2017c). Secretaria de Estado da Educação e do Desporto. Instituto Ayrton Senna. Metodologias Integradoras. SED/IAS (Coleção Educação Integral no Ensino Médio, Caderno nº 3).

Santa Catarina (2017a). Secretaria de Estado da Educação e do Desporto. Instituto Ayrton Senna. Núcleo Articulador. SED/IAS (Coleção Educação Integral no Ensino Médio, Caderno n ${ }^{\circ}$ ).

Santa Catarina (1998a). Secretaria de Estado da Educação e do Desporto. Proposta Curricular de Santa Catarina: Educação Infantil, Ensino Fundamental e Médio: Formação docente para educação infantil e séries iniciais. Florianópolis: COGEN.

Santa Catarina (1998b). Secretaria de Estado da Educação e do Desporto. Proposta Curricular de Santa Catarina: Educação Infantil, Ensino Fundamental e Médio: Temas multidisciplinares. Florianópolis: COGEN.

Santa Catarina (1998c). Secretaria de Estado da Educação e do Desporto. Proposta Curricular de Santa Catarina: Educação Infantil, Ensino Fundamental e Médio: Disciplinas curriculares. Florianópolis: COGEN.

Santa Catarina (2020). Secretaria de Estado da Educação. Currículo base do ensino médio do território catarinense. Secretaria de Estado da Educação.

Santa Catarina (2017h). Secretaria de Estado da Educação. Instituto Ayrton Senna. Um fio, um retalho, uma colcha: práticas de gestores inovadores. Florianópolis: SED/IAS.

Santa Catarina (2014). Secretaria de Estado da Educação. Proposta Curricular de Santa Catarina: formação integral na educação básica.

Santa Catarina (2000a). Tempo de Aprender: Subsídios às Classes de Aceleração de Aprendizagem nível 3 e para toda a Escola. Florianópolis: Diretoria de Ensino Fundamental/Diretoria de Ensino Médio.

Santa Catarina (2000b). Secretaria de Estado da Educação e do Desporto. Diretrizes para a organização da prática escolar na educação básica: ensino fundamental e ensino médio. Florianópolis: Diretoria de Ensino Fundamental/Diretoria de Ensino Médio.

Santa Catarina (2000c). Tempo de Aprender: Caderno do Aluno n ${ }^{o}$ 3. Florianópolis: Diretoria de Ensino Fundamental/Diretoria de Ensino Médio.

Saviani, D. A. (1995). A Filosofia da educação e o problema da inovação em educação. In: Garcia, Walter E. Inovação Educacional no Brasil: problemas e perspectivas. 3. ed. Campinas: Autores Associados.

Severino, A. J. Metodologia do trabalho científico. (22a ed.), Cortez, 2007.

Schultz, T. W. (1973). O capital humano: investimentos em educação e pesquisa. Zahar.

Stein, E. (2011). Inovação na Filosofia. Unijuí.

Tomazi, N. D. (2010). Sociologia para o ensino médio. (2a ed.), Saraiva. 